Научная жизнь

Чмыхова Е.В., Богоявленская Д.Б.

\title{
Междисциплинарная научно-практическая видеоконференция «Интеллектуальный потенциал российского общества: состояние и актуальные проблемы исследования»
}

Содействие развитию интеллектуальных ресурсов страны и формирование общества, основанного на знаниях важные для современной России задачи, которые требуют модернизации сферы образования. Россия фактически уже приступила к освоению модели всеобщего высшего образования. Три года подряд количество поступающих на первый курс вузов превышает число выпускников средних школ России, и с этим явлением приходится считаться. Необходимо тщательное и всестороннее изучение условий развития интеллектуальных способностей учащихся школ и вузов, разработка психолого-педагогического сопровождения учебного процесса.

Современная гуманитарная академия (СГА) ежегодно в апреле собирает ученых и преподавателей для обсуждения различных проблем, связанных с образовательным процессом. Эти встречи отличает междисциплинарный подход к заявленным в программе вопросам. Состоявшаяся 27 апреля 2006 года научно-практическая конференция была посвящена теоретическим и практическим аспектам изучения интеллектуального потенциала российского общества. В работе конференции, которая проходила одновременно в двух городах - в Москве и Санкт-Петербурге, соединенных телемостом, приняли участие научные сотрудники и 
преподаватели Современной гуманитарной академии, Психологического института РАО, МГУ им. М.В. Ломоносова, Института мозга человека РАН, Института социально-экономических проблем народонаселения РАН, ГУ - Высшей школы экономики, Института истории естествознания и техники РАН, Института психологии им. Л.С. Выготского РГГУ, Тель-Авивского университета и др. Гостями конференции были сотрудники Психиатрического Института «Вилла Салюс» из Италии, представители Национального комитета «Интеллектуальные ресурсы России» - исполнительный секретарь В.И. Панов и программный директор Всемирного форума «Интеллектуальная Россия» А.Н. Гудков. Вели конференцию доктор биологических наук, профессор С.А. Чепурнов, доктор психологических наук А.Л. Венгер, доктор психологических наук, профессор, председатель Московского отделения Российского психологического общества Д.Б. Богоявленская.

На открытии с приветственным словом выступили ректор СГА М.П. Карпенко и научный руководитель Института мозга человека РАН Н.П. Бехтерева. М.П Карпенко приветствуя участников конференции, отметил важность и актуальность заявленной темы. Ректор обратил внимание присутствующих на то, что недавно в Современной гуманитарной академии закончено масштабное исследование. Было опрошено несколько тысяч человек различного возраста, пола, мест проживания, получены очень интересные данные. Оказалось, что доля людей с высокими способностями составляет всего 10\%. Одаренные люди, заметил М.П. Карпенко, сумеют учиться даже в плохих условиях, а вот для людей со средними способностями, которых по результатам исследования примерно 70\%, нужна совершенная образовательная среда, индивидуальный подход к обучению. М.П. Карпенко подчеркнул, что нам придется давать высшее образование людям со средними способностями, и пожелал как можно дальше продвинуться в 
области когнитивной нейрологии и психологии обучения. В своем телевизионном приветствии конференции Н.П. Бехтерева подчеркнула, что начато удивительно важное, сложное на длительный период времени дело. Это озвучивания того, что делает мозг, когда студент обучается. Н.П. Бехтерева заметила, что активно работающий мозг позволяет даже в глубокой старости быть мыслящим и интересным человеком, а значит высшие учебные заведения, фактически, готовят людей для долголетия.

Прозвучавшие далее выступления обозначили основные проблемы исследования интеллектуального потенциала России и его состояние на данный момент. Открывал конференцию доклад И.В.Усольцевой (СГА), в котором были представлены результаты изучения интеллектуального потенциала России, выполненного в СГА. Исследование получило широкий охват и масштабность, поскольку в настоящее время. СГА - уникальный вуз, имеющий огромное количество учебных центров и представительств по всей России. Максимальное количество данных было собрано в возрастной группе подростков, так как именно они составят основу развития интеллектуального потенциала России в ближайшем будущем. Теоретическим аспектам интеллекта был посвящен доклад Н.И. Чуприковой (ПИ РАО), которая обратила внимание присутствующих на то, что знания современного человека отрывочны, ему присуще так называемое «клиповое мышление», ранняя специализация. Но всякое развитие должно идти в направлении от общего к частному согласно всеобщему универсальному закону развития всех органических систем природы и общества. Поэтому задача развития интеллекта состоит не только в том, чтобы у человека был большой жизненный опыт и обширные знания, но, прежде всего в том, чтобы все это отложилось в его голове в форме упорядоченной системы.

Невозможно представить способность к интеллектуальному творчеству вне интеллектуальной деятельности, но и творческие способности умственными не 
исчерпываются. Доклад Д.Б. Богоявленской (ПИ РАО) был посвящен последним данным по проблеме соотношения интеллекта и творческих способностей. Ею экспериментально установлено, что в зависимости от того, рассматривает ли человек решение проблемы как средство для осуществления внешних к познанию целей или оно само есть цель, определяется и судьба процесса. В первом случае он обрывается, как только решена проблема. Если же само познание есть цель - он развивается. Таким образом наблюдается феномен самодвижения деятельности, который приводит к выходу за пределы заданного. В этом выходе за пределы заданного, по ее мнению, и кроется тайна высших форм творчества. Вместе с тем, этот феномен не объясним только высотой интеллекта. То, что мы называем творческими способностями, считает Богоявленская, - это свойство целостной личности, отражающее взаимодействие когнитивной и аффективной сфер в их единстве. Рядом выступавших были предложены различные методы повышения уровня интеллектуального развития учащихся. Это доклады Е.Л. Яковлевой и Н.П. Локаловой (ПИ РАО), а также А.Л. Венгера (СГА). Сегодняшним студентам предстоит жить уже в другом по возрасту обществе. Теме интеллектуального потенциала старших возрастных когорт в Российской Федерации было посвящено выступление В.Г. Доброхлеб (ИСЭПН). Известно, что образованные, продолжающие получать новые знания и навыки, пожилые люди более успешно адаптируются к процессу старения. Л.М. Качалова (СГА) представила участникам конференции фильм о человеке, который в 81 год начал осваивать компьютерную грамотность, собирается получать высшее юридическое образование в СГА. Герой этого фильма, Г.П. Милорадов, также присутствовал на конференции. А.Н.Лебедев (ГУ- ВШЭ) предложил методику оценки личностных особенностей и интеллектуальных возможностей студентов. Конференция продолжилась в режиме прямого эфира из Санкт-Петербурга. С.Г. Данько в докладе 
«Психофизиологические

исследования

креативного

мышления: динамика ЭЭГ и локального мозгового кровотока», выполненного коллективом ученых Института мозга человека под руководством Н.П. Бехтеревой, отметил главную особенность данного исследования: «Мы стараемся выделить механизмы работы мозга непосредственно в деятельности с большей или меньшей креативной нагрузкой при максимальном уравновешивании других потенциально влияющих факторов». По окончании доклада прошла дискуссия между Москвой и Петербургом с участием итальянских гостей. П. Пинелли и его коллеги (ПИ «Вилла Салюс», Италия) ознакомили аудиторию с методикой, позволяющей выявить ранние нарушения когнитивных функций мозга на любой стадии развития.

Ю.П. Лежнина (СГА) представила слушателям доклад о том, каким образом интеллектуальный потенциал региона влияет на его социально-экономические показатели. Завершало конференцию выступление И.В. Богданова (СГА), в котором он рассказал о системе массового тестирования студентов как механизме управления качеством образования в вузе и предложил сравнивать вузы друг с другом именно по динамике перемен, происходящих в интеллектуальной сфере выпускников.

В заключительном слове, подводя итоги целого дня работы, Д.Б. Богоявленская отметила, что все многообразие представленных сообщений, очень интересных, продуктивных, как бы они не были различны, отвечают на один и тот же извечный вопрос, заданный давно Петраркой кто мы, что мы и куда идем. И психологические исследования, и социально-экономические отвечали на вопрос, что мы можем сделать, куда и как должно идти развитие нашей страны. Поэтому, все вместе мы, как представители сферы науки, выполняли свою гражданскую миссию, отвечая на этот актуальный и очень злободневный сегодня вопрос. 